\title{
READABILITY LEVEL OF ENGLISH READING TEXT USED IN THE ERA OF PANDEMIC
}

\author{
Mister Gidion Maru, Rida Paranduk, Javier Tuerah \\ Universitas Negeri Manado (UNIMA) Sulawesi Utara, Indonesia \\ Email: ridaparanduk554@gmail.com,mrgidionmaru@unima.ac.id, \\ javiertuerah@unma.ac.id
}

\begin{abstract}
This study attempts to investigate the readability level of the text used in the Junior High School. Taking the material from those read in the two prominent schools; public and private school. Being measured by the given formula and then followed by the given test to students, this study reveals that the readability level of four reading texts as the source of the data in this study indicates various level. It is only one out of four texts that was appropriate for 9th grade students. This affects the students' purpose of reading competencies of the students in private Junior school who have tendency toward unassisted reading than the students in the public school. It implies the number of students who need the instruction or need assisted in reading. The students within this school demand more instruction than those in private school. The similar condition shown in the students who categorized in the frustration level. As the consequences, this circumstance requires teacher's serious intervention among others by cautiously doing text selection and adjusting teaching strategy to students' reading level competency.
\end{abstract}

Keywords: reading text; readability; junior high school

\section{Introduction}

Reading text is a crucial material for language learners in gaining knowledge and improving their reading skill. It becomes the fundamental media for the learners to access knowledge. (Bergström \& Jervelycke Belfrage, 2018) point out, as the media, the text included on the complex interaction between the reader and the activity of reading which at the end of this interaction results the product: reading comprehension. That is reasonable when reading text generally views as an important medium to improve students' reading comprehension that most used in academic subject (Guo, Baker, Dall'Anese, Hu, \& Summers, 2018). Seeing how important the reading text is, the appropriate reading material is needed. This condition requires the language practitioners included teachers to aware on the appropriate of reading text that can affect to the students' comprehension, reading skill and knowledge improvement.

Due to this, language practitioners need to be aware of the characteristics of appropriate reading texts at students' level. (Fitzgerald et al., 2015) point out three most

$\begin{array}{ll}\text { How to cite: } & \text { Maru, M. G., Paranduk, R., Tuerah, J. (2021) Readability Level of English Reading Text Used in The } \\ & \text { Era of Pandemic. Syntax Literate: Jurnal Ilmiah Indonesia. 6(7). http://dx.doi.org/10.36418/ syntax- } \\ & \text { literate.v6i7.3557 } \\ \text { E-ISSN: } & \text { 2548-1398 } \\ \text { Published by: } & \text { Ridwan Institute }\end{array}$


important text characteristics were at the sentence and discourse level intersentential complexity, text density/information load, and phrase diversity (the longest common string operationalization). Another point of view as summarizes by O'Reilly and (Zarella, 2010), the characteristics of text deals with its coherence and coefficient. Which means the degree of concepts, ideas, and relations within a text are explicit has been referred to text cohesion, whereas text coherence deals with the effect of text cohesion on readers' comprehension. In line (Streit \& Nuttall, 1982) point out three criteria to be the consideration in selecting a text, namely: readability, suitability, and exploitability.

In fact, not all language practitioners are aware on this condition. By learning from some literatures show the fact that the reading text often not at the level of students. This condition stimulates researchers to make the research in such field. One of the areas that interest the researchers is analyzing readability level of texts. It can be seen from numerous researches who have been conducted their study on analyzing the text level readability. Among others, (Yulianto, 2019) He analyzed the readability level of eight text books for eight grader by means of flesch readability formula. He found, from eight reading texts, there are only one text is relevant for seven to eight grader. Since six texts are suitable for elementary school and one text for Senior High School. In similar interest (Turkben, 2019) counts the readability level of Turkish textbooks. He analyzes Turkish textbooks according to the Ateşman formula. He found, the average sentence lengths of certain informative texts are above from the number. In his final analysis he argues that the majority of the texts in Turkish textbooks are at the level of easy.

However, deals with difficulty or easy of a text Snow argues it depends on inherent factor in the text, on the relationship between the text and the readers' knowledge and abilities, and on the activities in which the reader is engaged 2002. Similarly, from the complexity perspectives (Fitzgerald et al., 2015) claims, the text complexity is relative on the readers' population at different ages or reading capability. In this case the teacher has an essential role to judge students capability to find the suitable text on the students' level. As the solution for this diversity, (Reinders, Nunan, \& Zou, 2017) suggest that ideally, the space for negotiation in the classroom is important to be created by the teacher. There are by considering the students' level of proficiency, catering the needs of individual learners, and provide opportunities for the improvement. In line (Bahmani \& Farvadin, 2017) suggest that ideally, teachers should consider the value of self-selected materials as a key to a successful implementation of English Reading.

Weather the text is easy or difficult it gives various effects to the students. (Mikeladze \& Mikeladze, 2014) claims that a difficult or unreadable book influences the students to abandon. However, (Burns \& Siegel, 2017) argue that the students can be both motivated and challenged when they read the text higher on their level. Furthermore (Tekşan, Süğümlü, \& Çinpolat, 2020) show the fact on the effect of both difficult and easy text. They found that an accomplished reader will be getting bored 
while they are reading texts which consist of simple words and simple sentences but a lower-level reader will be bored while they are reading a texts which consist of long words and sentences, which will cause both readers stopping reading the texts. Similarly, (Reinders et al., 2017) show the fact that this condition affects the difficulty of finding suitable teaching materials for Academic Purposes from many published materials on the Chinese market. Language proficiency which is one of the gaps. They state that, the authentic materials makes the low proficiency students get misunderstanding or misinterpretation; on the contrary, the higher language proficiency students may bore in reading lower-level texts. From these facts, it can be seen that the level of ease or difficulty of the text can have different effects on the way students read.

Factually in this current era, the students required having the qualified reading comprehension proficiency. Now comprehension test is not only used in final examination but also in competitions for entrance tests in favorite schools or colleges and can even be a prerequisite for getting a job. This condition requires students to having qualified abilities in order to pass the test which is usually followed by passing grade as its prerequisite. The requirement of passing the test stimulates the reader to improve their capability independently. Schools can no longer track students so that only those with highly developed reading skills take the more reading-intensive courses (Burns \& Siegel, 2017). This can be a sign and a challenge for the teacher to use complex reading text in teaching reading comprehension to make the students familiar in comprehending the difficult reading text. Otherwise, as a consequence to students who are only focus on short and simple reading text, they will become overwhelm in facing this current condition.

Based on the assumptions above, it appears that there will be differences in the development of vocabulary acquisition for those who are only accustomed to using simple text in learning and those who are m using texts with a high level of difficulty. The students who are only focus on simple text impact to their lack of vocabulary. It tends to impact on how they comprehend the reading text since they have low background knowledge. This case also impact to the readability of text. (Bailin \& Grafstein, 2016) argue, one of a case that may impact to readability is the difficulty which is affected by the lack of readers' contextual knowledge in comprehending the meaning of text. This condition can be seen clearly in the case of the lack of vocabulary. The text will be difficult for the readers when they find many unfamiliar words.

By learning from the researcher's experience as a teacher and through literature review there are many reading texts are not at the level of students, in fact most of teacher do not realize on it because the information of text readability is not included on most of the text book. It is included on the students' additional reading text during these pandemic of covid-19 used in some Junior High Schools in Bitung.For these reasons the researcher interested to focus her study on measuring the readability of text used by the teacher in Junior High Schools in Bitung in this era of pandemic. Based on the researcher's initial review of related literature, even though there are many articles 
concerning on readability from various perspectives butthere were no recent study has been conducted to measure these texts. The researcher argues that there is a need to determine the readability of the additional reading text during these pandemic of covid19.

The concept of readability has been discussed for a long time by language practitioners. It can be seen in (DuBay, 2004) as in his following reviews. (DuBay, 2004) defines readability is what makes some texts easier to read than others. Further he reviews four old definitions of readability. The definitions are from (Klare, 1963), (McLaughlin, 1969), (Hargis, 2000), and (Dale \& Chall, 1949). (Klare, 1963) in defines readability as "the ease of understanding or comprehension due to the style of writing." In a similar manner, Gretchen Hargis and her colleagues at IBM 1998 in state that "readability, the 'ease of reading words and sentences,' is an attribute of clarity". The creator of the SMOG readability formula (McLaughlin, 1969) in defines readability as: "the degree to which a given class of people find certain reading matter compelling and comprehensible." (Dale \& Chall, 1949) in (DuBay, 2004), they divine the readability as "The sum total (including all the interactions) of all those elements within a given piece of printed material that affect the success a group of readers have with it. The success is the extent to which they understand it, read it at an optimal speed, and find it interesting."

Specifically (Bailin \& Grafstein, 2016) propose three basic concept of textual comprehension that can best used to understand the concept of 'readability'. There are linking of units of information, ambiguity, and background knowledge. They explain those three basic concepts as in the following explanation: First deals with concept of 'linking'. Linking refers to the reader's capability to connect the element of information on the word, sentence, or discourse level. Second deals with concept of 'ambiguity'. They argue, as another property of a text 'ambiguity' can affect the readers' comprehensibility. Ambiguity refers to the possibility of multiple meanings. e. g. the word chair as noun can refer to something one sits on, or it can refer to a person who is functioning as the head of an organizational unit such as a committee or academic department. Third, deals with the concept of 'contextual (background) knowledge'. This refers not only to any information used by the readers to form their assumption of text but also the conclusion stated in the text that used by the readers in order to interpret subsequent parts of the text.

Readability formulas estimate how difficult text is to read. The result of "readability level" can be a reference for the teacher to match students on their appropriate books. (Chen \& Meurers, 2018) state, to assign text at the proper level to the readers at different levels of proficiency needed the assessment of text readability. Discussing the assessment of text readability level of course will be connected to the method to measure the readability of text, whether the measurement method is using an application or manually. The following will give a little discussion deals with the formula to measure readability level of text. 
As various studies in the field of readability were discussed, linguists were interested in discussing formulas for measuring the level of readability. The formula of readability has been formulated for a long time. Among others, Lucius Adelno Sherman a professor of English Literature at the University of Nebraska, in 1880 started to teach literature at historical and statistical point of view in. Even though he did not created a readability formula yet, but he showed how his principles worked by using manual method in comparing the older prose writers with more popular modern one such as Macaulay and R. A. Emersor. Based on the result of comparison he noticed a progressive shortening of sentences over time Sherman in (DuBay, 2004). Further, (DuBay, 2004) claims the first readability formula was formulated by Bertha Lively and S. L. Pressey in 1923. Started from their focus area on the practical problem of selecting science textbooks for junior high school. They found the problem on many technical words that spent teachers' time to focus their teaching in vocabulary. They argue to measure the vocabulary level and minimize the vocabulary burden of text book. The first children's readability formula was presented in their article. It measured the number of different words in each 1,000 words and the number of words not on the Thorndike list of 10,000 words. Their method produced a correlation coefficient of .80 when tested on 700 books. They explained, if a formula should predict a 9th-grade level of difficulty on a 7th grade text, and, if at all grade levels, the error is in the same direction and by a corresponding amount, the correlation could be +1.00 or at least quite high. If, on the other hand, a formula predicts a 9th-grade level for a 6th-grade text, an 8th grade level for a 10th-grade text, and has similar variability in both directions, the correlation would be very low, or even 0.00 .

Cloze test can be modified for several purposes. It not only can be used for measuring text readability but also an individual's understanding of a text (Tailor in (DuBay, 2004). In line Radice in (Dessi, 2015) suggested that cloze test can be used to differentiate between achievement levels and to test reading comprehension (Dessi, 2015). Moreover, (Brown \& Abeywickrama, 2010) reviewed, for several decades, in assessing reading the cloze testing was a very popular procedure. It was based on the consideration that the cloze test hasintegrative nature as if offered a practical ways to test overall comprehension somewhat indirectly.

Based on (DuBay, 2004) described the way to construct a cloze test and the purpose of requirement score. He stated that a cloze test uses a text with regularly deleted words (usually every fifth word) and requires the subjects to fill in the blanks. The percentage of words correctly entered is the cloze score. He explained that, the lower thescore, the more difficult the text. (DuBay, 2004) considered even advanced readers cannot correctly complete more than $65 \%$ of the deleted words correctly in a simple text. He categorized the requirement score for assisted reading was $35 \%$ or more. While the texts for unassisted reading need a higher score. Cloze test could be formatted in the form of multiple-choice. It provides some choices of key answers. (DuBay, 2004) figured the cloze scores line up with scores from multiple-choice tests in the following manner: 
Table 1

Comparison of Cloze and Multiple-Choice Scores (DuBay, 2004)

\begin{tabular}{lcc}
\multicolumn{1}{c}{ Purpose } & Cloze & Multiple-choice \\
\hline Unassisted reading & $50-60 \%$ & $70-80 \%$ \\
\hline Instructional, assisted reading & $35-50 \%$ & $50-60 \%$ \\
\hline Frustration level & Below 35\% & Below 50\% \\
\hline
\end{tabular}

In addition, there are many formulas for measuring the readability of the reading text. But, this study used Flesch Readability Formula which is considered as the more popular formula. Moreover, the researcher used cloze text in order to measure the students understanding of text.

Claimed (DuBay, 2004) that Flesch's Reading Ease formula became the most widely used formula and one of the most tested and reliable.Flesh's readability formulas used the number of syllables and the number of sentences for each 100-word sample as its variable. Fleschin (DuBay, 2004) described, this formula predicts reading ease on a scale from 1 to 100 , with 30 being "very difficult" and 70 being "easy."

Thus, based on this background in mind, in this present study the researcher focuses onthree research aims, there are to analyze:

1. The readability of reading texts of 9th grade students in SMP Kristen Madidir and SMP N. 6 Bitung as the additional texts used in the pandemic era;

2. The students' comprehension achievement on these texts;

3. The teachers' teaching strategy used in teaching these texts.

\section{Reasearch Methods}

The mixed methods research had been designed in thisstudy, as it combined the numerical and qualitative at the stage of collection and analysis the data. The sources of the data were documents, students, and teachers. All the data used in this study were obtained through the document, the students of 9th grade, and the English teacher. The document was English Reading Text for 9th grade: PembelajaranBerbasisAktivitas: Sebuah Alternatif Pembelajaran Jarak Jauh. This book was specially published by the Ministry of Education and Culture as an alternative to learning from home due to the pandemic.

The readability tool application, cloze test, and interviewwere used as the instruments in obtaining the data. There were aimed to obtain the information of the reading text readability used by the 9th grade students in SMP N. 6 Bitung and SMP Kristen Madidir, the students' comprehension achievement and teacher strategy in teaching and in overcoming students problem. There were administered as in the following procedure:

1. Readability tool application used in this study was Microsoft word application. It was used as the easier way to get the flesch score. Here the Flesch Reading Easy formula is automatically coded in this application so the readability statistical was easy and 
quickly to compute and to access. After getting the readability statistics or flesch score, it compared with the description of Flesch's Reading Ease Scores as in the table1.

2. Cloze test: the test was designed in the form of objective test where the correct answer were available to be chosen. It was set as in following example

3. Example of multiple-choice

A flood is one of natural ...(1)... that caused by an overflow water that submerges land which is usually dry. The European Union (EU) Floods Directive water flood as a covering by water of land not normally covered by water. Some floods can occur suddenly and quickly.
a. disasters
b. water
c. overflow
d. danger

To validate the instrument the researcher made a consultation with the expert to make sure whether or not the test was relevant and reliable with the core competence, indicators, learning material as well as the form of the test.

As the participants were taken from 2 different schools, the tests distributed differently. 15 sets of cloze test's hardcopy were delivered to 15 students in grade 9th of SMP Kristen Madidir. Here in this school applied offline learning system but still obey the social distancing to avoid the spread of corona virus. The other participants were 35 students in SMP N. 6 Bitung. The researcher did the test through Google Form online for the similar reason of social distancing to avoid the spread of corona virus. This school applied online and offline learning class but only one online class took part as the participants in this study.

4. Interview: The interview was administered to get the qualitative data from the teachers. To do the interview, the researcher as the interviewer followed some expert suggestions i.e. (Estabrooks, Field, \& Morse, 1994), (Weerawardena, Mort, Salunke, Knight, \& Liesch, 2015). They suggested the interviewer should:

a. Avoiding interruptions from outside e.g. phone cell calling

b. jumping from one topic to another

c. giving advice or opinions rather than active listening

d. summarizing too early or closing off an interview too soon

e. appear to be interested

f. be prepared to repeat questions at the respondent's request

g. giving time to respondent in answering the questions.

The researcher used her phone-cell in the process of documentation and recording the interviewing. Further, the data from interviewing process were analyzed by using the qualitative data analysis (Pfeffer et al., 2014) suggestedtheir model of qualitative data analysis. This consisted of data condensation, data display and drawing/ verifying the conclusion. In condensation process, the data collection were summarized into the brief data, focused into the essential points, focused to the theme, and discarded the unimportant data. Next, the data displayed after being condensed. There were displayed in good organizing and arranging into the correlative pattern in order to make the data easier to be understood. The last step of 
analyzing the interviewing data was drawingor verifying the conclusion. The conclusion were draw by analyzing the displaying data.

A deeper information related with teachers' strategy and the way they overcome students' problem dig in this interview. The interview was set in informal situation so the participants felt relax in sharing the information during the interview. It was not conducted together for both participants but they were separated in different schedule.

5. Participants:

a. Forty nine students of 9th grade which were taken from two schools consist of: One group's offline learning class from SMP Kristen Madidir and one online class at SMP N. 6 Bitung which consist of thirty four students.

b. Two participants were taken from English teachers at SMP Kristen Madidir and SMP N. 6 Bitung. They were considered as experience teacher since they had been teaching English for more than 15 years.

\section{Results and Discussion}

1. Texts Readability

There were four texts from English Reading Text for 9th grade: Pembelajaran Berbasis Aktivitas: Sebuah Alternatif Pembelajaran Jarak Jauh. This book was specially published by the Ministry of Education and Culture as an alternative to learning from home due to the pandemic. Based on the process of checking the readability score by means aMicrosoft word application, the following result were presented as follows:

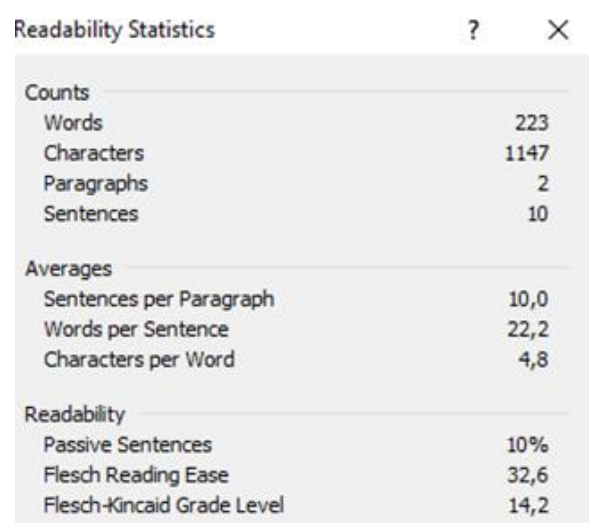

Picture 1

Soursop (See The Appendix 1 for Complete Text)

As this present research used Flesch Reading Easy formula so this was focus on the second last information of the readability statistics above. By comparing with the Flesch's Reading Ease Scores criteria as presented in the table 1, it can be interpreted that text 1 was categorized as difficult text and it was estimated for 13 th to 16th grade. 
Mister Gidion Maru, Rida Paranduk, Javier Tuerah

$\begin{array}{lr}\text { Readability Statistics } & \text { ? } \\ \text { Counts } & \\ \text { Words } & 217 \\ \text { Characters } & 1032 \\ \text { Paragraphs } & 6 \\ \text { Sentences } & 10 \\ \text { Averages } & \\ \quad \text { Sentences per Paragraph } & 2,0 \\ \quad \text { Words per Sentence } & 21,5 \\ \text { Characters per Word } & 4,6 \\ \text { Readability } & \\ \quad \text { Passive Sentences } & \\ \text { Flesch Reading Ease } & 50 \% \\ \text { Flesch-Kincaid Grade Level } & 58,3 \\ & 10,4\end{array}$

\section{Picture 2}

\section{Aloe Vera (See The Appendix 2 for Complete Text)}

The reading ease score as being presented in readability statistics above is 58,3. By comparing with Flesch's Reading Ease Scores criteria it could be interpreted that text 2 was categorized as fairly difficult and it was estimated for 10 th to 12 th grade.

\begin{tabular}{lr}
\hline Readability Statistics & ? \\
Counts & \\
Words & 212 \\
Characters & 944 \\
Paragraphs & 2 \\
Sentences & 18 \\
Averages & \\
Sentences per Paragraph & 18,0 \\
Words per Sentence & 11,7 \\
Characters per Word & 4,2 \\
& \\
Readablity & \\
Passive Sentences & \\
Flesch Reading Ease & \\
Flesch-Kincaid Grade Level & 71,0 \\
\end{tabular}

Picture 3

Guava (See Appendix 4 for Complete Text)

The reading ease score as being presented in readability statistics above is 71.0. By comparing with the Flesch's Reading Ease Scores criteria it could be interpreted that text 3 was categorized as fairly easy and it was estimated for 7 th grade. 


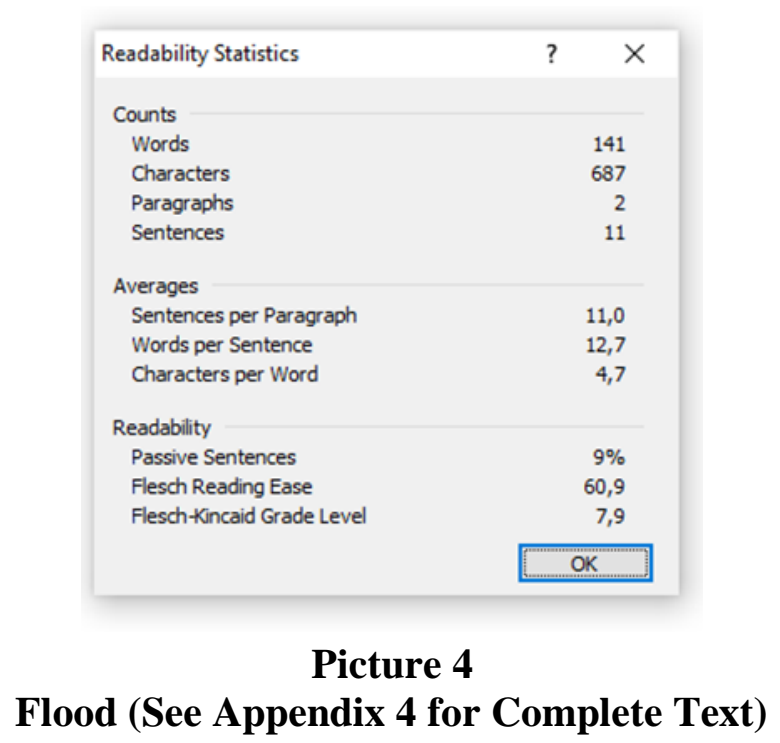

The reading ease score as being presented in readability statistics above is 60,9. By comparing with the Flesch's Reading Ease Scores criteriait could be interpreted that text 4 was categorized as standard and it was estimated for 8 th and 9thgrade. In short the readability statistics of texts above presented in the following table:

Table 2

Presentation of Reading Texts Readability

\begin{tabular}{cccc}
\hline Text & Flesch Reading Ease Score & Style Description & Estimated reading grade \\
\hline Text 1 & 32,6 & Difficult & $13^{\text {th }}$ to $16^{\text {th }}$ grade \\
\hline Text 2 & 58,3 & Fairly Difficult & $10^{\text {th }}$ to $12^{\text {th }}$ grade \\
\hline Text 3 & 71,0 & Fairly Easy & $7^{\text {th }}$ grade \\
\hline Text 4 & 60,9 & Standard & $8^{\text {th }}$ and $9^{\text {th }}$ grade \\
\hline
\end{tabular}

As explained by (DuBay, 2004) the lower the score, the more difficult the text. It clearly shows from the table that the readability level of all texts were in various level. Only one out of four texts was appropriate for 9th grade students. The most difficult is text one since its flesch reading ease score is the lowest. It is the most difficult text so did not appropriate even for Senior High level. It was best understood by the college level. The flesch reading ease score of text two were higher than text one score but still not appropriate for 9th grade because it upper then the standard score for 9th grade students. Since the highest score was in text three that categorized fairly easy level so it was appropriate for 7 th grade students.

Inappropriate level of reading text readability impact to students way of learning. As discuss in the introduction of this study that an accomplished reader will be getting bored while they are reading texts which consider easy howevera lower-level reader will be bored while they are reading difficult text. This will cause both readers stopping reading the texts. 
2. Cloze test

The second objective in this study was aimed at finding out the students' comprehension achievement on the texts. The researcher used multiple-choice cloze text in order to measure the students reading comprehension.So, the result of students' achievement in cloze test needs to be presented as in the following table:

Table 3

Description of Cloze Test Result of SMP Kristen Madidir Bitung Purpose Cloze Multiple-choice Frequency Relative

\begin{tabular}{|c|c|c|c|}
\hline Purpose & Cloze Multiple-choice & Frequency & $\begin{array}{c}\text { Relative } \\
\text { Frequency }(\%)\end{array}$ \\
\hline Unassisted reading & $70-80 \%$ & 4 & 26,67 \\
\hline Instructional, assisted reading & $50-60 \%$ & 6 & 40,00 \\
\hline Frustration level & Below $50 \%$ & 5 & 33,33 \\
\hline \multicolumn{2}{|l|}{ Total } & 15 & 100 \\
\hline \multicolumn{2}{|c|}{ Mean Score } & 53,57 & \\
\hline \multicolumn{2}{|c|}{ St. Dev. } & 13,22 & \\
\hline
\end{tabular}

The present result shows that the mean score is 53,57 with the standard deviation 13,22 which shows that the scores are widely dispersed around the mean score. $26,667 \%$ students got the result between 70 to $80 \%$ or 4 out of 15 students categorized as unassisted reading. $40 \%$ students got the result between 50 to 60 or 6 out of 15 students need to be assisted in reading activity. There are 33,33\% or 5 out of 15 are low level students which categorized as frustration level. Next the data were presented as in the following histogram.

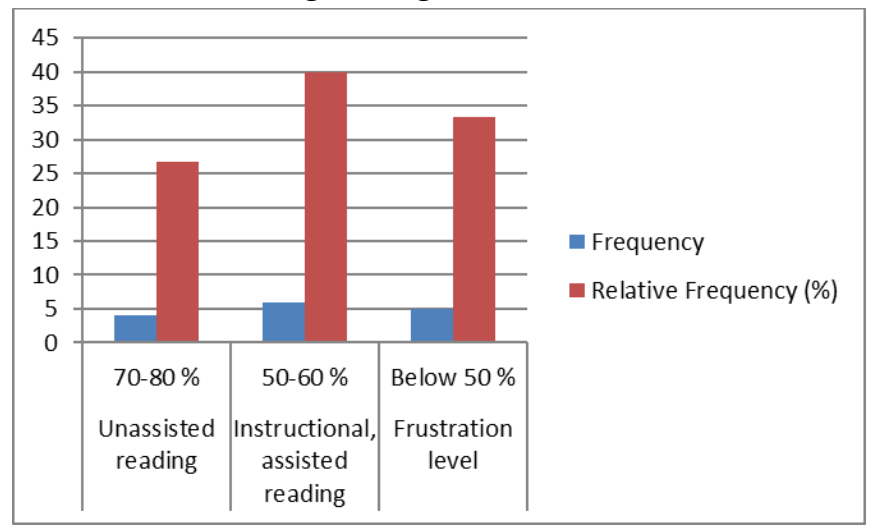

Picture 5

The Histogram of Students at SMP Kr. Madidir Cloze Test Result

Tabel 4

Description of Cloze Test Result Of SMPN 6 Bitung

\begin{tabular}{lcccc}
\hline \multicolumn{1}{c}{ Purpose } & Cloze Multiple-choice & Frequency & $\begin{array}{c}\text { Relative } \\
\text { Frequency (\%) }\end{array}$ \\
\hline Unassisted reading & $70-80 \%$ & 6 & 17,65 \\
\hline Instructional, assisted reading & $50-60 \%$ & 15 & 44,12 \\
\hline Frustration level & Below 50\% & 13 & 38,24 \\
\hline \multicolumn{2}{c}{ Total } & & 34 & 100 \\
\hline \multicolumn{2}{c}{ Mean Score } & 54 & \\
\hline St. Dev. & 13 & \\
\hline
\end{tabular}


The present result shows that the mean score is 54 with the standard deviation 13 which shows that the scores are widely dispersed around the mean score. 17,65\% students got the result between 70 to $80 \%$ or 6 out of 34 students categorized as unassisted reading. $44,12 \%$ students got the result between 50 to 60 or 15 out of 34 students need to be assisted in reading activity. There are $38,24 \%$ or 13 out of 34 students are low level students which categorized as frustration level. Next, the data were presented as in the following histogram.

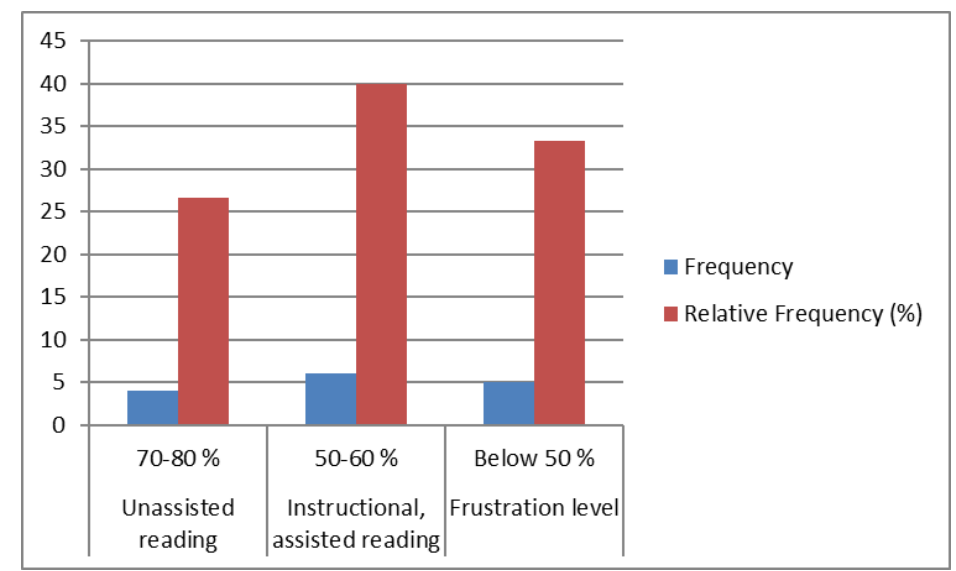

Picture 6

The Histogram of Students At SMPN 6 Bitung Cloze Test Result

Table 5

\begin{tabular}{ccc}
\multicolumn{3}{c}{ Comparison of Cloze Test Result } \\
\hline Data & $\begin{array}{c}\text { SMP Kristen } \\
\text { Madidir Bitung }\end{array}$ & SMPN 6 Bitung \\
& 15 & 34 \\
\hline N & 55 & 54 \\
\hline Mean & 14 & 13 \\
\hline St.Dev. & 75 & 75 \\
\hline Max Score & 25 & 25 \\
\hline Min Score & 50 & 50 \\
\hline Median & 45 & 50 \\
\hline Mode & $26,67 \%$ & $17,65 \%$ \\
\hline Unassisted reading & $40,00 \%$ & $44,12 \%$ \\
\hline Instructional, assisted reading & $33,33 \%$ & $38,24 \%$ \\
\hline Frustration level & &
\end{tabular}

It can be seen from the table that the students in SMP Kristen Madidir Bitung and SMP N. 6 Bitung almost similar in their level of reading. It can be seen from the mean score and the spread of students score to the mean score almost similar. Moreover they have similar maximum score and minimum score. Dealing with students' purpose of their level of reading competencies, SMP Kristen Madidir Bitung have more Unassisted reading than the students in SMP N. 6 Bitung. It impact to the number of students who are need the instruction or need assisted in 
reading the SMP N. Bitung need more instruction than SMP Kristen Madidir Bitung. The similar condition shown in the students who categorized as frustration level. The students in SMP N. 6 Bitung have more low level than those in SMP Kristen Madidir . The way teacher overcome this condition is going to present in the following result of interview.

3. Interview

Two main themes in the interview are:

a. The teachers' teaching strategy used in teaching these texts.

b. The way teachers overcome the students' condition according on their level of reading competence.

The participants take part in the process of interview and the results are displayed as follow:

a. Finding on teachers' teaching strategy used in teaching these texts.

In order to dig the deeper information from the English teachers in both schools the open-ended interview was carried out. The results are as the following result. Teacher 1, SMP Kristen Madidir, (Monday, Feb. 1st. 14.00 p.m. - 15.30 p.m.).

"The pandemic affected to learning and teaching activity thatdemands tochangethe way of learning and teaching activity.Optimizing the shorter times which was scheduled only 30 minutes per meeting as a ways to avoid from the corona virus.Problem Based Learning model used in classroom activity.The students not only learn at school but also motivated to continue learning after school.The studentsdirected to learn at home independently. Some students can find and solve the problem independently sohere the teacher's role was observation. They are categorized higher level students. They activity such as searching the solution on google and dictionary.However the dependent students need teacher's guidance."

Problem Based Leaning model is considered suitable to be applied to the students at SMP Kristen Madidir reading classroom where the time allocated only 30 minutes in a meeting due to the pandemic. This school conducted offline class for the reason that many students are not supported by gadget including good internet access. Even the meeting set in offline class that teacher and students are possible in face to face activity, but still influences to the way they learning and teaching. In this learning situation requires the students to take part independently. It can be seen from the information from 1st participant above. 30 minutes meeting is not enough for teacher to create such a discussion class, or guiding all students one by one rather than guide them classically to train themselves to be creative in overcome their own problem. It is hope that the students should not stop their learning activity in class. However, they have to continue it at home. With the prior consideration they have found their problem (in this case reading) to be solved independently at home.In line with one of characteristics of Problem Based Learning asmentioned by (Lin, Ansarian, Tik, \& Nair, 2019) that isself-directed 
learning. (Olaizola et al., 2019) put Independent and self- directed learning as a prior principlein Problem Based Learning. Especially (Raza et al., 2019) emphasizes that Problem-based learning is a teaching method in which students' learn through the complex and open ended problems. Moreoverhe states, this real world problems are able to encourage students' learning through principles and concept.

Besides, the activity in this class showthe way students recognize the problem are different according to their level of competencies. It appears that for higher level students are able to recognize their problem in reading independently. But of course the teacher does not completely let them to learn on their own. However the teacher observetheir activity. Different with the lower level students activity. It shows that they need teacher guidance in the process of recognize the problem and solving it as well. Teacher 2, SMP N. 6 Bitung, (Tuesday, Feb. 2nd. 14.00 p.m. -15.30 p.m.).

"Conducted online class activity using google meet application. The teachers are required to prepare the soft copy material and students worksheet or LKPD (LembarKerjaPesertaDidik). The soft copy material is specially published by the Ministry of Education and Culture as an alternative to learning from home due to the pandemic. The material is English Reading Text for 9th grade: Pembelajaran Berbasis Aktivitas: Sebuah Alternatif Pembelajaran Jarak Jauh. It is sent into 9th graders' group Whats-App, the students are easy to search the material in this e-book. To support it, the students' worksheet is sent to English google classroom in order to make the class more effective."

Opposite with the 1st participant's school, in SMP N.6 Bitung conducted online learning. This online remote learning or pembelajaran jarak jauh dalam jaringan (daring) is one of Ministry of Education and Culture's program. It isregulated in SE no. 15 thn. 2020 about learning implementation guidelines from home in an emergency of the spread of corona virus disease (covid-19).To run theonline classroom activity they used google meet application. It appear the students and teacher are supported with smart phone and good internet access. In order to conduct the online class of course both smart phone and internet access should available. It cannot run only with smart phone without good internet access and vice versa. It is not only required for students but also for teacher. By this online learning activity is very helpful and safety to avoid the spread of corona virus. They can learn safety from home without afraid of the crowded.

However as a ways to optimize online class, the online material as well as students worksheet are needed. As a consequencethe teachers in SMP N. 6 Bitung are required to prepare material to support this online class. It is in the form of soft copy and the teacher required to distribute the file to online group classroom. It shows that the 2nd participant as an English teacher sent the soft copy of the 
material to 9th graders' whats-app group. Luckily the government has published the electronic books included for English subject for 9th grader studentsentitled English Reading Text for 9th grade: Pembelajaran Berbasis Aktivitas: Sebuah Alternatif Pembelajaran Jarak Jauh. This book is specially published by the Ministry of Education and Culture as an alternative to learning from home due to the pandemic. This is a kinds of interventions that shows by the government to the Indonesian students included SMP N. 6 Bitung. As some of the advantages of usage the electronic book are distributing and searching for e-books is less expensive than regular book, moreover it is easier to carry than printed books due to their weight and small size (Ravzatillo, 2020). So it is done by the 2nd participant, the English e-book isdistributed easily into 9th graders' group whatsapp and students are easily to search the presented topic.

Besides the e-book, the teacher should prepare the students worksheet named Lembar Kerja Peserta Didik. (Semple \& Lee, 2014) suggested, deals with academic achievement, the worksheets can be useful in many ways. He gives the example, it useful as supplements to textbooks, worksheets can be used to add information for particular classes. Moreover he claim that Instructional written materials such as students worksheet play important roles as teachers' agents in effective teaching practices. It connected with in the participant's online class as the students' worksheetused as the supplement to e-book to make the teaching and learning more effective. It does not send in Whats-app group but other application namedgoogle classroom.It is specially created by the English teacher for the 9th grader English students. So it is specially managed by the 9th grade English teacher without connected to other subject such as Math, Science, etc. That makes this application different in used with the whats-app group since WA group is joined together with all subjects in 9th grade. In this application allowed teachers and students to create and manage paperless classes, assignments as well as grades online. It is in line with (Nasrullah, Marlina, \& Dwiyanti, 2018) opinion that the student's paperless worksheet encourages students to use it outside the classroom by using the Internet. Teachers' way to overcome different students' level of reading comprehension.

b. Teachers' way to overcome different students' level of reading comprehension

To see the ways teacher overcome this condition are clearly show on the teacher 1 and 2 answers on the question about teachers' way to overcome different students' level of reading comprehension. It can be seen teacher 1 and 2 have similar responds. Both teacher conducted enrichment program for the students who are reach the passing grade. Meanwhile for the students who are not reach the passing grade they give them remedial. They did the similar program since it became a standardize in educational system in Indonesia, since it regulated in curriculum 2013 as stated in the assessment guide published by the ministry of education and culture 2016. In this assessment guide 2016 regulated, after evaluating students' learning outcomes whether it reach the passing grade or not, 
the students who are not reach the passing grade yet should follow the remedial, meanwhile, the students who are reach out the passing grade can be given the enrichment. In line with (Khan, 2017), he reminds the first step in working on a students' weaknesses is diagnosis the problem and after that there are several ways to initiate this process and attain the predetermined objectives. The remedial program is aimed at students who categorize the lower level of competencies so they the improvements. They need to improve scores that are lacking or do not reach the KKM. Meanwhile, the enrichment activities arranged by the teacher for students aim to make students more able to impose their knowledge on the specified competencies. From the interview, the teacher 1 and 2 give the supplement task based on curriculum's standard of competences for the students who are pass the passing grade or cut score.

The teacher give more depth assignment to be done at home for the students who get the enrichment program. For the students who get the remedial give vary activity such as ask classmates who are consider capable to guide them as peer tutors or teacher's guidance.

\section{Conclusion}

Based on the information in this research the level of text difficulties are relative on the readers' population at different ages or reading competencies. The fact shows here, the reading text often not at the level of students. The findings of this research show that the readability level of all texts indicates various level. It discloses that it is merely one out of four texts was appropriate for 9th grade students which influences students' purpose of reading. Further, SMP Kristen Madidir Bitung have more Unassisted reading than the students in SMP N. 6 Bitung which determines the number of students who require the instruction or need assisted in reading.. The students of frustration level is low in public junior school. As the consequences this situation, it is necessary for teacher's intervention which includes appropriating of text and teaching strategy in teaching to various level of students reading level competency. 


\section{BIBLIOGRAPHY}

Bahmani, Roghayeh, \& Farvadin, Mohammad Taghi. (2017). Effects of different text difficulty levels on EFL learners' foreign language anxiety and reading comprehension. Google Scholar

Bailin, Alan, \& Grafstein, Ann. (2016). Readability: Text and context. Springer. Google Scholar

Bergström, Annika, \& Jervelycke Belfrage, Maria. (2018). News in social media: Incidental consumption and the role of opinion leaders. Digital Journalism, 6(5), 583-598. Google Scholar

Brown, H. Douglas, \& Abeywickrama, Priyanvada. (2010). Language assessment: Principles and classroom practices (Vol. 10). Pearson Education White Plains, NY. Google Scholar

Burns, Anne, \& Siegel, Joseph. (2017). International perspectives on teaching the four skills in ELT: Listening, speaking, reading, writing. Springer. Google Scholar

Chen, Xiaobin, \& Meurers, Detmar. (2018). Word frequency and readability: Predicting the text-level readability with a lexical-level attribute. Journal of Research in Reading, 41(3), 486-510. Google Scholar

Dale, Edgar, \& Chall, Jeanne S. (1949). Techniques for selecting and writing readable materials. Elementary English, 26(5), 250-258. Google Scholar

Dessi, Arvinda. (2015). Comparative Study Between Multiple Choice and Cloze Test toward Students' Reading Achievement at the second grade of SMP N 3 Sawahlunto. STKIP PGRI Sumatera Barat. Google Scholar

DuBay, William H. (2004). The Principles of Readability. Online Submission. Google Scholar

Estabrooks, Carole A., Field, Peggy Anne, \& Morse, Janice M. (1994). Aggregating qualitative findings: an approach to theory development. Qualitative Health Research, 4(4), 503-511. Google Scholar

Fitzgerald, Jill, Elmore, Jeff, Koons, Heather, Hiebert, Elfrieda H., Bowen, Kimberly, Sanford-Moore, Eleanor E., \& Stenner, A. Jackson. (2015). Important text characteristics for early-grades text complexity. Journal of Educational Psychology, 107(1), 4. Google Scholar

Guo, Yi, Baker, Kyri, Dall'Anese, Emiliano, Hu, Zechun, \& Summers, Tyler Holt. (2018). Data-based distributionally robust stochastic optimal power flow-Part I: Methodologies. IEEE Transactions on Power Systems, 34(2), 1483-1492. Google Scholar 
Hargis, Gretchen. (2000). Readability and computer documentation. ACM Journal of Computer Documentation (JCD), 24(3), 122-131. Google Scholar

Khan, Hamed. (2017). OSCEs are outdated: clinical skills assessment should be centred around workplace-based assessments (WPBAS) to put the 'art'back into medicine. MedEdPublish, 6. Google Scholar

Klare, George Roger. (1963). Measurement of readability. Google Scholar

Lin, Teoh Mei, Ansarian, Loghman, Tik, Ong Lok, \& Nair, Anne Benedict. (2019). The effects of problem-based language learning on the listening comprehension skills of Malaysian undergraduate students. Journal of Asia TEFL, 16(3), 996. Google Scholar

McLaughlin, G. Harry. (1969). Reading at" impossible" speeds. Journal of Reading, 12(6), 449-510. Google Scholar

Mikeladze, Tamar, \& Mikeladze, T. (2014). Extensive reading. Telavi: Telavi Lakob Gogebashvili State University. Google Scholar

Nasrullah, Anton, Marlina, Mira, \& Dwiyanti, Widya. (2018). Development of Student Worksheet-Based College E-Learning Through Edmodo to Maximize the Results of Learning and Motivation in Economic Mathematics Learning. International Journal of Emerging Technologies in Learning, 13(12). Google Scholar

Olaizola, B., Garnsworthy, A. B., Ali, F. A., Andreoiu, C., Ball, G. C., Bernier, N., Bidaman, H., Bildstein, V., Bowry, M., \& Caballero-Folch, R. (2019). Shape coexistence in the neutron-deficient lead region: A systematic study of lifetimes in the even-even Hg 188-200 with the GRIFFIN spectrometer at TRIUMF. Physical Review C, 100(2), 24301. Google Scholar

Pfeffer, W. Tad, Arendt, Anthony A., Bliss, Andrew, Bolch, Tobias, Cogley, J. Graham, Gardner, Alex S., Hagen, Jon Ove, Hock, Regine, Kaser, Georg, \& Kienholz, Christian. (2014). The Randolph Glacier Inventory: a globally complete inventory of glaciers. Journal of Glaciology, 60(221), 537-552. Google Scholar

Raza, A., Iqra, U., Azhar, N., Hussain, I., Khan, M. U., Bano, S., Rubab, A., Sajid, S. N., Bukhari, S. A. H., \& Haider, Z. (2019). Characterization of Selected Plants Leaves with Particular Emphasizes on Epidermis. Haya Saudi Journal of Life Sciences, 4(9), 326-330. Google Scholar

Reinders, Hayo, Nunan, David, \& Zou, Bin. (2017). Innovation in Language Learning and Teaching. Springer. Google Scholar

Semple, Randye J., \& Lee, Jennifer. (2014). Mindfulness-based cognitive therapy for children. In Mindfulness-based treatment approaches (pp. 161-188). Elsevier. Google Scholar 
Streit, R. L., \& Nuttall, A. H. (1982). A general Chebyshev complex function approximation procedure and an application to beamforming. The Journal of the Acoustical Society of America, 72(1), 181-190. Google Scholar

Tekşan, Keziban, Süğümlü, Üzeyir, \& Çinpolat, Enes. (2020). Readability of Turkish tales. Journal of Language and Linguistic Studies, 16(2), 978-992. Google Scholar

Turkben, Tuncay. (2019). Readability Characteristics of Texts in Middle School Turkish Textbooks. Educational Policy Analysis and Strategic Research, 14(3), 80-105. Google Scholar

Weerawardena, Jay, Mort, Gillian Sullivan, Salunke, Sandeep, Knight, Gary, \& Liesch, Peter W. (2015). The role of the market sub-system and the socio-technical subsystem in innovation and firm performance: A dynamic capabilities approach. Journal of the Academy of Marketing Science, 43(2), 221-239. Google Scholar

Yulianto, Yulianto. (2019). An Analysis on Readability of English Reading Texts With Automated Computer Tool. J-SHMIC: Journal of English for Academic, 6(1), 8191. Google Scholar

Zarella, D. (2010). The Social Media Marketing Book. Sebastopol. Kanada: O'reilly. Google Scholar

\section{Copyright holder:}

Mister Gidion Maru, Rida Paranduk, Javier Tuerah (2021)

First publication right:

Syntax Literate: Jurnal Ilmiah Indonesia

This article is licensed under:

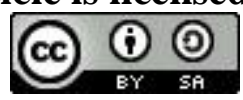

